\section{Yhteiskunnallisen vaikuttamisen lyhyt historia}

Heikkilä, Markku \& Karisto, Antti (2017). Lahden keskuksesta Palmeniaksi. Helsingin yliopiston koulutus- ja kehittämiskeskus yhteiskunnallisen vaikuttamisen asialla. Päijät-Hämeen tutkimusseura. 176 sivua.

TEOS KERTOO PALMENIANA tUnnetun koulutus- ja kehittämiskeskuksen vaiheista aina 1970-luvun puolivälistä, Lahden keskuksen alusta. Tarkastelussa on kronologisesti laitoksen koko elinkaari toiminnan merkittävään alasajoon saakka vuonna 2016. Lahden näkökulma painottuu käsittelyssä.

Yliopiston laitoshistoriikkeja on ilmestynyt useita, ja Turussa tehtiin vastaavasta laitoksesta oma historiikki jo vuonna 2005, Henri Terhon laatima Yliopiston ja yhteiskunnan palveluksessa. Avoimesta yliopistosta lienee myös olemassa omia tapahtuneen kehityksen tarkasteluja. Tässä mielessä Heikkilän ja Kariston teos ei ole ainutlaatuinen.

Se on kuitenkin huolellisesti tehty ja hyvin dokumentoitu. Tekijät ovat uhranneet vaivaa haastatteluja myöten, ja henkilökuntaa on osallistettu kertomaan työstään. Teosta elävöittävät kuvituksen lisäksi luonnehdinnat johtajien toimintatavoista ja -tyyleistä. Eräiden rehtoreiden vahva ja asian kannalta merkittävä uudistusmielisyys kuvataan sattuvasti.

Kirja on tärkeä, koska se antaa lukijalle käsityksen yliopiston yhteiskunnallisen tehtävän toteutumisesta täydennyskoulutuksen ja kehittämistoiminnan kautta.
Tarkastelu kattaa myös avoimen yliopiston vaiheita vuoteen 2004 saakka.

\section{TALOUDEN EHDOT SANELIVAT}

\section{KEHITYKSEN}

Kirjassa kuvatut tapahtumat ovat tuttuja muissa vastaavissa laitoksissa eri yliopistoissa: melko yhtenäiset taloudelliset ehdot ovat saaneet aikaan samansuuntaista kehitystä muuallakin. Kirjassa on kiinnostavia näkökohtia niille, ovat olleet tekemisissä yliopiston kolmannen tehtävän tai avoimen yliopiston kanssa.

Moni koulutus- ja kehittämiskeskus on saanut alkunsa alueiden korkeakoulupaineiden purkamisesta. Lahden keskus vastasi tarpeisiin saada yliopiston osa tai ainakin korkeakouluopetusta paikkakunnalle. Lahti panosti asiaan lahjoittamalla virkoja tai toimia keskukseen sen alkuvaiheissa. Paineita oli eri puolilla Etelä-Suomea ja muuallakin, ja kunnat olivat aktiivisesti mukana toiminnan laajentamisessa. Näin Palmenia levittäytyi Imatraa, Kotkaa, Kouvolaa, Siuntiota ja Lohjaa myöten. Kasvu oli henkilömääräisestikin huomattavaa.

Teoksen parasta antia ovat laitoksen koulutus- ja kehittämistoiminnan sisällölliset tarkastelut.

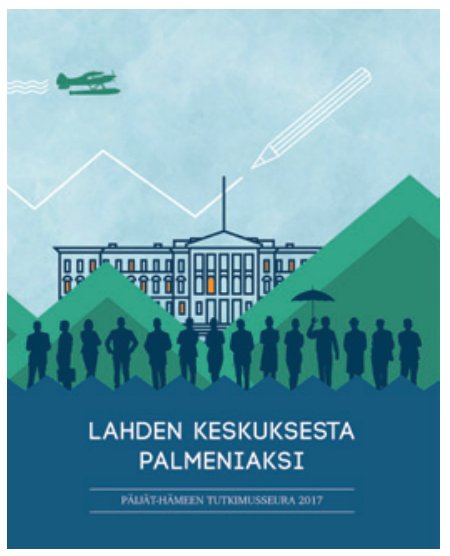

Aktiviteettien kirjo oli valtava. Tähän liittyvät mainiosti muistelut alan pioneerien, kuten yliopiston suunnittelutoimiston päällikön Heikki Lammen, räiskyvästä ideoinnista. Käytännön yhteistyössä syntyneet ideat olivat asiakaslähtöisen toiminnan ydintä. Verkostomainen, tiedelaitosten professoreita, ministeriön asiantuntijavirkamiehiä sekä yritysten ja kuntien edustajia osallistava työtapa innosti ja toi tuloksia. Toiminnassa oli runsaasti vapausasteita, mikä oli tärkeää uusien ideoiden synnylle. Yhteistyön laajuutta ja ideoiden runsautta voi todella ihailla ja kaivatakin näin jälkikäteen.

\section{KEHITTÄMISEN PIONEERIT}

Pitkät työllisyyskoulutukset muodostuivat tärkeäksi oppimisen paikaksi niin Lahden keskukselle kuin muille vastaaville laitoksille. Lahti oli edelläkävijä: vuonna 1985 käynnistyi jo 120. työllisyyskurssi. Koulutusten kirjo oli suuri: elinkeinoasiamiehet, matkailuala, 


\section{TUTKIMUSTA, KEHITYSHANKKEITA}

JA VÄITÖSKIRJOJA.

tukset olivat lähtökohta myöhemmille asiantuntijakoulutuksille.

Teoksessa kuvataan lisäksi lyhyesti erilaisia kehittämisprojekteja, selvityksiä ja matkailun kehittämishankkeita, joita tehtiin Sodankylää ja Tuusniemeä myöten. Eivätkä hankkeet rajoittuneet pelkästään Suomeen, vaan laitoksen pioneerit sukelsivat rohkeasti kehitysyhteistyöhankkeisiin. Hankkeiden ja pitkien koulutusten yhteiskunnallisten vaikutusten arviointi olisi mielenkiintoinen aihepiiri, mutta se menee historiikin tehtävän ulkopuolelle.

\section{VERKKO-OPETUKSEN EDELLÄKÄVIJÄ}

Lahden keskuksessa virisi etä- ja monimuoto-opetus, joka oli ajasta ja paikasta vapaata ja joka vaikutti vähitellen koko yliopistoon. Palmenian ja muiden koulutus- ja kehittämiskeskusten ja avointen yliopistojen rooli monimuotoopetuksen kehittämisessä ja elinikäisen oppimisen idean edistämisessä oli tärkeä koko suomalaiselle aikuiskoulutukselle.

Lahden keskukseen perustettu tutkimusosasto lienee ainoa koulutus- ja kehittämiskeskus, jossa laajemmin tehtiin soveltavaa tutkimusta sosiaalipolitiikan, aikuiskoulutuksen, yrityskehittämisen ja ympäristötieteiden alueella. Syntyi myös väitöskirjoja. Täydennyskoulutusyksiköt ovat olleet hyvä koulutus- ja kehityspaikka monille nuorille maistereille oppia käytännön työntekoa. Monet sosiaali- ja koulutuspolitiikan vaikuttajat sekä virkamiehet ovat saaneet niistä vauhtia uralleen.

Historiikista käy ilmi, miten hankalasti yliopistoon jäsentyvän osan koulutus- ja kehittämiskeskuksen toiminnallinen kokonaisuus muodosti. Osin oli tarvetta organisoida voimakkaasti kasvanutta laitosta uudelleen, mutta joistakin viitteistä voi päätellä, että dynaamisen täydennyskoulutusyksikön ja perinteisen yliopistolaitoksen byrokratia ja valtarakenteet olivat jonkinlaisessa ristiriidassa. Tekijät esittelevät yksityiskohtaisesti hallinnollisia kuvioita etenkin teoksen alkupuolella. Vaikka ratkaisu hiukan haittaa luettavuutta, kuvaukset laitoksen alasajosta ovat kiinnostavia.

\section{MISSÄ NYT VIRITELLÄÄN IDEOITA?}

Kehittämistoiminta ja täydennyskoulutus koskettivat monia henkilöitä, ja luovuutta esiintyi paljon. Villit ideat saivat rehottaa kokeilukentällä. Missä nyt kehitellään käytäntölähtöisiä yliopistolliseen tutkimukseen liittyviä yhteiskun- nan ja alueiden kehittämiseen liittyviä uusia ideoita? Taloudelliset ehdot ovat toki muuttuneet. Siitä huolimatta näyttää, että Palmenian ja samankaltaisten laitosten lakkauttamisessa tai alasajossa ei arvioitu oikein toimintojen yhteiskunnallista vaikuttavuutta.

Ovatko yliopistot kadottamassa tärkeän osan kolmannesta tehtävästään?

\section{ESKO PAAKKOLA}

KT

Kirjoittaja on Itä-Suomen yliopiston koulutus- ja kehittämispalvelu

Aducaten entinen johtaja. 